\title{
BUR TELEGE : ETNOGRAFI GERAKAN KOLEKTIF MASYARAKAT DALAM MEMBANGUN WISATA ISLAMI
}

\author{
Ade Ikhsan Kamil 1 , Iromi Ilham² , Siti Ikramatoun3 , Richa Meliza4, \\ Sjafruddin 5 \\ 1,2,4 Program Studi Antropologi, Universitas Malikussaleh Lhokseumawe \\ 3 Program Studi Sosiologi Univeristas Syiah Kuala Banda Aceh \\ 5 Program Studi Administrasi Bisnis, Universitas Malikussaleh, Lhokseumawe \\ Korespondensi: ade.ikhsan.kamil@unimal.ac.id
}

\begin{abstract}
Abstrak: Lahirnya Undang-Undang No. 6 Tahun 2014 membuka peluang bagi desa untuk mandiri dan otonom. Keistimewaan tersebut salah satunya untuk berpartisipasi dalam peningkatan ekonomi masyarakat melalui pengembangan kawasan wisata islami. Berdasarkan hal tersebut, kebangkitan pariwisata Buttelege membuka asa baru dalam penelitian tentang desa. Oleh karena itu, penelitian ini dilakukan bertujuan untuk mengkaji 3 hal utama, pertama; bagaimana proses awal munculnya ide untuk membangun daerah Pariwisata Burtelege dengan memanfaatkan dana desa. Kedua; mellihat bagaimana dampak sosial, peruubahan dan perkembangan. Ketiga; mengkaji negosiasi yang dibangun oleh inisiator dalam menjawab tantangan hadirnya wacana wisata islami. Dengan menggunakan pendekatan etnografi, penelitian ini bertujuan mengeksplorasi dinamika sosial-ekonomi terkait dengan pengembangan kawasan wisata Burtelege. Hasil penelitian menunjukkan bahwa ada faktor awal dari pembangunan dan pengembangan Burtelege sebagai kawasan wisata.tiga faktor tersebut adalah keinginan untuk mengubah stereotip kampung, mengembalikan keaktifan pemuda dan keinginan mengorganisasikan parkir di hari Minggu sebagai stimulan. Selain itu, partisipasi masyarakat berupa kegiatan swadaya telah menstimulus perkembangan Burtelege sebagai kawasan wisata islami.
\end{abstract}

Kata Kunci: Etnografi, Pemanfaaatan Dana Desa, Pembangunan Pariwisata, Burtelege, 


\section{A. Pendahuluan}

Tidak ada yang meragukan nikmatnya kopi Arabica Gayo. Aroma dan viskositasnya yang kuat, sepadan dalam melahirkan cita rasa yang khas. Berada pada lekukan indah gunung vulkanik menjadi alasan utama mengapa biji kopi Gayo terkenal hingga ke mancanegara. Saat ini, tanah Gayo tidak hanya dikenal sebagai daerah penghasil kopi, namun juga disebut sebagai daerah yang memiliki potensi wisata alam yang fenomenal. Bahkan, wisata alam di tanah Gayo yang bernama Bur Telege ramai diperbincangkan para wisatawan satu tahun terakhir.

Merujuk pada Peraturan Menteri Desa Nomor 22 Tahun 2016 tentang Penetapan Prioritas Penggunaan Dana Desa Tahun 2017, dinyatakan bahwa selain untuk mendanai penyelenggaraan pemerintahan dan pembangunan infrastruktur, Dana Desa dapat digunakan untuk pembinaan dan pemberdayaan masyarakat. Artinya, ada peluang untuk menggunakan dana desa dalam hal-hal yang produktif serta bisa mendatangkan pendapatan bagi masyarakat dan daerahnya. Salah satunya adalah dengan mengembangkan sektor pariwisata islami. Karena tak bisa dipungkiri, banyak penelitian yang menyatakan bahwa jika sektor pariwisata diperhatikan maka perekonomian akan meningkat sehingga menguntungkan masyarakat mulai dari tingkat nasional, regional maupun lokal (lihat, Walpole \& Goodwin, 2000; Putra \& Heddy Shri, 2014).

Sejalan dengan itu, kala Bur Telege menyediakan panorama indah yang bisa dinikmati, peluang pembangunan pariwisata pun hadir di sana. Letaknya geografisnya yang berada pada ketinggian 1250 mdpl sungguh menawarkan panorama alam yang tidak biasa. Lokasinya yang bersisian dengan danau laut tawar, menambah daya tarik tersendiri bagi pengunjung, bahkan danau kebanggaan masyarakat Gayo, juga kota Takengon bisa dinikmati dari puncak Bur Telege. (Lihat, Serambinews.com; "Bur Telege, Objek Wisata Baru di Takengon”). Berdasarkan hasil observasi dan wawancara awal penulis, mulanya pembangunan objek wisata Bur Telege ini adalah hasil inisiatif para pemuda, pemerintah desa dan masyarakat setempat. Mereka secara bersama-sama menyulap hutan pinus yang penuh semak belukar, "sarang maksiat" menjadi daerah wisata fenomenal dengan memanfaatkan Dana Desa (lihat, Serambinews.com; "Sarang Maksiat Itu 
Kini Jadi Lokasi Wisata). Berbekal dana desa yang ada, Desa Bale yang dulu kerap disebut masuk dalam wilayah marginal kini tidak bisa lagi dilihat sebelah mata. Bur Telege menjadi salah satu produk kebudayaan desa di sektor pariwisata yang berkembang pesat.

Secara sosiologis, usaha masyarakat Desa Bale menyulap hutan pinus dan sarang maksiat menjadi objek wisata tersebut bukanlah sesuatu yang biasa, lebihlebih dalam konteks Aceh. Tentu ada banyak hal yang menjadi tantangan tersendiri bagi pemerintah dan masayarakat ketika ide tersebut dimulai. Terutama tantangan dari berbagai institusi dalam masyarakat ketika konsep pariwisata dibenturkan dengan Aceh yang menganut Syariat Islam. Apalagi kehadiran objek wisata selalu beriringan dengan masuknya nilai-nilai budaya baru yang kemudian akan mempengaruhi nilai-nilai budaya lama yang ada dalam masyarakat.

Pada titik inilah, artikel ini dimulai. Artikel ini ingin mengkaji lebih lanjut bagaimana proses pemanfaatan dana desa terhadap pembangunan pariwisata Bur Telege yang terletak di desa Bale serta menggali bagaimana implikasi sosial akibat lahirnya tempat pariwisata tersebut. Tentu saja, hal ini berbicara tentang perubahan dan perkembangan kebudayaan akibat kegiatan pariwisata. Di samping itu, penulis ingin mengetahui bagaimana negosiasi-negosiasi yang dilakukan oleh para inisiator dalam menjawab tantangan-tantangan yang hadir ketika wacana daerah wisata itu dibentuk.

Beberapa literatur yang memuat mengenai desa pasca lahirnya Undangundang Desa pada dasarnya sudah banyak dilakukan, tetapi sebagian besar masih berbicara mengenai aspek partisipasi, efektifitas dan akuntabilitas penggunaan dana desa. Dalam konteks aceh, belum ditemukan kajian yang terkait dengan penggunaan dana desa dalam pembangunan pariwisata meskipun potensi pariwisata alam Aceh sangant besar.

Studi yang dirujuk pada artikel ini adalah yang telah dilakukan oleh Sutoro Eko, dkk (2014) yang mengkaji tentang desa sebagai subjek pembangunan yang melibatkan masyarakat sebagai unsur utama (self Development) dan Community . Kedua, Hary Hermawan (2016) dimana hasil penelitiannya menyebutkan bahwa aktifitas pengembangan Desa Wisata memiliki korelasi positif terhadap perekonomian masyarakat desa. Dengan pengembangan desa wisata yang 
dilakukan dapat meningkatkan kunjungan wisatawan dan kunjungan tersebut kemudian berpengaruh pada intensitas perekonomian warga yang semakin meningkat. Ketiga, penelitian Faizatul Karimah, dkk (2014) berjudul "Pengelolaan Alokasi Dana Desa dalam Pemberdayaan Masyarakat". Dalam penelitian, Karimah dkk menemukan bahwa pengelolaan dana desa masih di didominasi oleh kepala desa dalam setiap tahapan pengelolaan alokasi dana desa mulai dari perencanaan, mekanisme penyaluran dan pencairan dana, pelaksanaan, pengawasan, pertanggungjawaban sampai pada transparansi anggaran.

Keempat, hasil penelitian Ramainim Saragih dan Sarwititi Agung (2017). Hasil penelitian ini menyatakan bahwa terdapat beberapa indikasi yang menunjukkan bahwa masih terdapat ketidakjelasan mengenai program penggunaan dan prioritas penggunaan dana desa. Salah satu penyebabnya adalah penyusunan RPJM Desa-RKP Desa yang tidak sesuai dengan kebutuhan serta aspirasi masyarakat. Penyebab lainnya adalah kurangnya pelibatan masyarakat sejak proses awal sampai akhir program, sehingga perencanaan tersebut disusun tidak sesuai dengan kebutuhan.

\section{Desa \& Dana Desa}

Dalam perkembangannya, persepektif tentang desa mengalami perubahan seiring dengan perubahan regulasi tentang desa. Desa yang pada masa dulu diposisikan sebagai organisasi pemerintahan yang berada dalam sistem pemerintahan kabupaten/ kota (local state government) dengan asas desentralisasi- residualitas, dan saat ini desa diposisikan sebagai pemerintahan masyarakat, yaitu hybrid antara self governing community dan local self government. Selain itu, UU No. 6/2014 tentang desa juga telah menegaskan komitmen politik dan konstitusional bahwa negara melindungi dan memberdayakan desa agar menjadi kuat, maju, mandiri, dan demokratis sehingga dapat menciptakan landasan yang kokoh dalam melaksanakan pemerintahan dan pembangunan Menuju masyarakat Yang adil, makmur, dan sejahtera (Kemenkeu, 2017: 1). Berikut ini perbedaan persepektif desa pada masa lalu dan desa masa kini berdasarkan regulasi yang ada (Eko, 2014: 11): 


\section{Perspektif Desa Lama vs Desa Baru}

\begin{tabular}{|c|c|c|}
\hline & Desa Lama & Desa Baru \\
\hline Payung Hukum & $\begin{array}{l}\text { UU No. 32/2004 dan PP No. } \\
72 / 2005\end{array}$ & UU No. $6 / 2004$ \\
\hline Asas Utama & Desentralisasi-residualitas & Rekognisi-subsidianitas \\
\hline Kedudukan & $\begin{array}{l}\text { Sebagai } \\
\text { pemerintahan yang berada } \\
\text { dalam sistem pemerintahan } \\
\text { kabupaten/ kota (local state } \\
\text { government) }\end{array}$ & $\begin{array}{l}\text { Sebagai pemerintahan masyarakat, } \\
\text { hybrid antara self governing } \\
\text { community dan local self government. }\end{array}$ \\
\hline $\begin{array}{l}\text { Posisi dan peran } \\
\text { kabupaten/kota }\end{array}$ & $\begin{array}{l}\text { Kabupaten/kota mempunyai } \\
\text { kewenangan yang besar dan } \\
\text { luas dalam mengatur dan } \\
\text { mengurus desa. }\end{array}$ & $\begin{array}{l}\text { Kabupaten/kota } \\
\text { kewenangan yang terbatas dan } \\
\text { strategis dalam mengatur dan } \\
\text { mengurus desa; termasuk mengatur } \\
\text { dan mengurus bidang urusan desa } \\
\text { yang tidak perlu ditangani langsung } \\
\text { oleh pusat. }\end{array}$ \\
\hline $\begin{array}{l}\text { Delivery } \\
\text { kewenangan dan } \\
\text { program }\end{array}$ & Target & Mandat \\
\hline Politik tempat & $\begin{array}{l}\text { Lokasi: Desa sebagai lokasi } \\
\text { proyek dari atas }\end{array}$ & $\begin{array}{l}\text { Arena: Desa sebagai arena bagi orang } \\
\text { desa untuk menyelenggarakan } \\
\text { Pemerintahan, pembangunan, } \\
\text { pemberdayaan dan kemasyarakatan }\end{array}$ \\
\hline $\begin{array}{l}\text { Posisi dalam } \\
\text { pembangunan }\end{array}$ & Objek & Subjek \\
\hline $\begin{array}{l}\text { Model } \\
\text { Pembangunan }\end{array}$ & $\begin{array}{lr}\text { Government } & \text { driven } \\
\text { development atau community } & \text { coment }\end{array}$ & Village driven development \\
\hline $\begin{array}{l}\text { Pendekatan dan } \\
\text { tindakan }\end{array}$ & $\begin{array}{l}\text { Imposisi dan multilasi } \\
\text { sektoral }\end{array}$ & Fasilitas, emansipasi dan kon-salidasi \\
\hline
\end{tabular}

(Sumber: Sutoro Eko, 2014)

\section{Konsep dan Teori Pemberdayaan}

Konsep Pemberdayaan Masyarakat lahir sebagai antithesis terhadap model pembangunan yang kurang memihak pada mayoritas rakyat. Pemberdayaan masyarakat juga diartikan sebagai upaya untuk membantu masyarakat dalam mengembangkan kemampuan sendiri sehingga bebas dan mampu untuk mengatasi masalah dan mengambil keputusan secara mandiri. Ini berarti bahwa pemberdayaan masyarakat ditujukan untuk mendorong terciptanya kekuatan dan kemampuan lembaga masyarakat untuk secara mandiri mampu mengelola dirinya sendiri berdasarkan kebutuhan masyarakat itu sendiri serta mampu mengatasi tantangan persoalan dimasa yang akan datang. Untuk merealisasikan itu, Setiana (dalam Abidin, 2012: 201-202) menyatakan bahwa ada tiga jenis kekuatan yang patut diperhatikan dalam upaya pemberdayaan masyarakat, yaitu; kekuatan 
Pendorong (motivational forces), kekuatan bertahan (resistance forces) dan kekuatan pengganggu (interference forces).

Menurut Wilson (1996) siklus pemberdayaan masayarakat harus melewati 7 (tujuh) tahapan. Pertama yaitu keinginan dari masyarakat sendiri untuk berubah menjadi lebih baik. Kedua, memampuan masayarkat melepaskan faktor-faktor yang resisten terhadap kemajuan dalam dirinya dan komunitasnya. Ketiga, masyarakat diharapkan sudah menerima kebebasan tambahan dan merasa memiliki tanggungjawab dalam mengembangkan dirinya dan komunitasnya. Keempat, mengembangkan peran dan batas tanggungjawab yang lebih luas. Pada tahap kelima ini hasil-hasil nyata dari pemberdayaan mulai nampak, yakni terjadi peningkatan rasa memiliki dalam masyaarakat. Tahap keenam, adanya perubahan perilaku dalam masyarakat. Pada tahap ketujuh masyarakat yang telah berhasil dalam memberdayakan dirinya, merasa tertantang untuk upaya yang lebih besar guna mendapatkan hasil yang lebih baik. Siklus pemberdayaan ini menggambarkan proses mengenai upaya individu dan komunitas untuk mengikuti perjalanan kearah prestasi dan kepuasan individu dan pekerjaan yang lebih tinggi. Berikut ini siklus pemberdayaan masyarakat dalam suatu komunitas menurut Wilson:

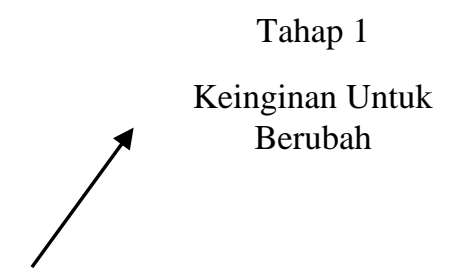

Tahap 7

Merasa tertantang untuk usaha yang lebih besar

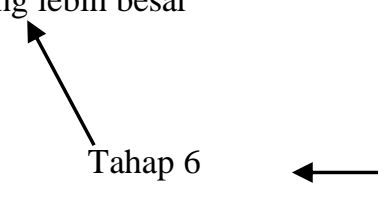

Perubahan perilaku

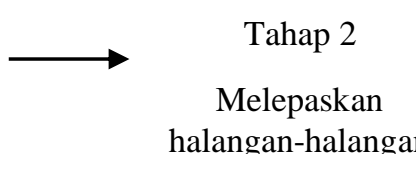

Tahap 5

Pencapaian hasil dan target yang lebih besar

Sumber: Wilson (1996)

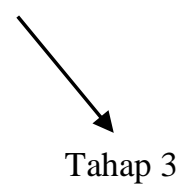

Rasa memiliki bertambah

Tahap 4

Mengembangkan peran dan tanggungiawab 
Untuk merealisasikan dan memudahkan proses tersebut di atas, Wilson (1996) juga menyatakan bahwa ada empat tahanpan yang harus dilakukan dalam proses pemberdayaan, yaitu:

1. Awakening atau penyadaran, artinya masyarakat disadarkan akan kemampuan, sikap dan keterampilan yang dimiliki serta rencana dan harapan akan kondisi mereka yang lebih baik dan efektif.

2. Understanding atau pemahaman, yaitu memberikan pemahaman dan persepsi baru mengenai diri mereka sendiri, aspirasi mereka dan keadaan umum lainnya. Proses pemahaman ini meliputi proses belajar untuk secara utuh menghargai pemberdayaan dan tentang apa yang dituntut dari mereka oleh komunitas.

3. Harnessing atau memanfaatkan, setelah masyarakat sadar dan mengerti mengenai pemberdayaan, saatnya mereka memutuskan untuk menggunakannya bagi kepentingan komunitasnya.

4. Using, yaitu menggunakan keterampilan dan kemampuan pemberdayaan sebagai bagian dari kehidupan sehari-hari.

\section{B. Metode Penelitian}

Penelitian ini dilaksanakan di Desa Bale, Takengon Aceh Tengah. Pemilihan Desa Bale sebagai lokasi penelitian mempertimbangkan beberapa alasan berikut;

1. Terjadinya diversifikasi mata pencaharian karena menurunnya produktivitas kopi.

2. Pengembangan kawasan Bur Telege sebagai kawasan pariwisata meningkat secara pesat dalam tahun ini. Perkembangan tersebut secara otomatis meningkatkan keinginan masyarakat untuk mengembangkan kawasan pariwisata tersebut untuk tujuan ekonomi.

3. Kawasan Bur Telege memiliki nilai historisitas yang panjang terkait dengan keberadaan beberapa situs agama yang mulai ramai dikunjungi akhir-akhir ini.

4. Sumberdaya manusia di Bur Telege sebagai kawasan tengah Aceh selalu dipandang dalam kacamata yang perifer sebagai kawasan yang hanya memanfaatkan komoditas kopi. 
5. Memiliki keunikan-keunikan, yaitu lokalitas dari interaksi masyarakat.

\section{Tahapan Pengumpulan Data dan Teknik Pengujian Keabsahan Data}

Tahapan pengumpulan data pada penelitian ini terdiri dari (Bungin, 2010):

1. Studi literatur

2. Observasi partisipasi

3. Wawancara mendalam

Setelah semua data dikumpulkan melalui berbagai teknik pengumpulan data seperti diatas, maka peneliti akan melakukan analisa data akan dilakukan secara induktif dimana para peneliti membangun pola-pola, kategori-kategori dan tema- temanya dari bawah ke atas, dengan mengolah data ke dalam unit-unit informasi yang lebih abstrak. Pada akhirnya, penelitian ini akan menghasilkan sebuah gambaran yang kompleks dari suatu masalah atau isu yang diteliti (Creswell, 2010: 261). Secara garis besar, proses analisis data akan dilakukan seperti skema berikut ini:

\section{Skema Triangulasi Data}

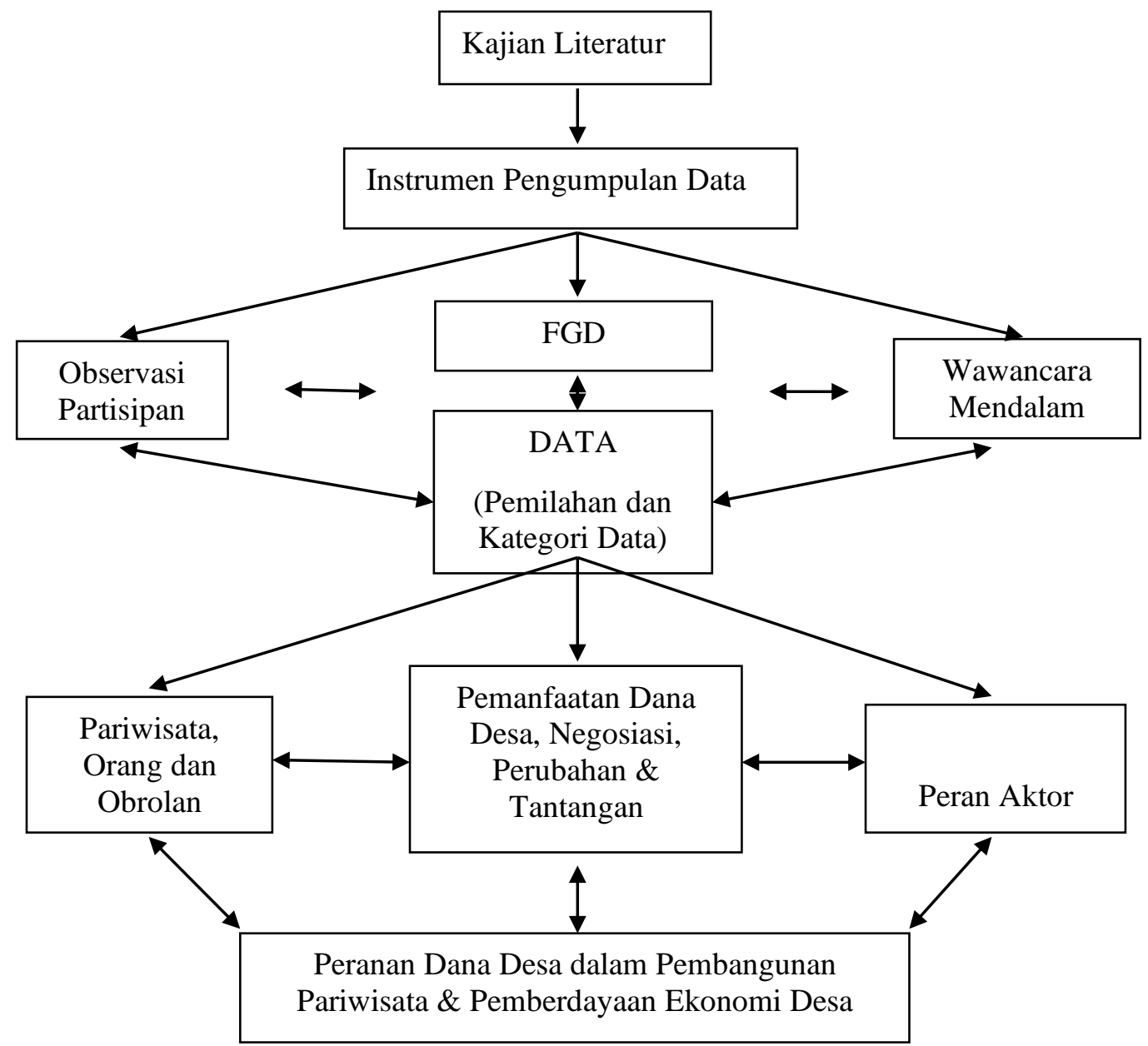

Kamil , Ilham, Ikramatoun, Meliza, Sjafruddin : Bur Telege: Etnografi Gerakan ... 


\section{Burtelege Bangkit : Keinginan Untuk Berubah}

\section{Deskripsi Singkat Bur Telege}

Bukit Bur Telege berlokasi di Kampung Hakim Bale Bujang, Kecamatan Lut Tawar, Kabupaten Aceh Tengah. Bukit ini merupakan salah satu bukit barisan yang berkesinambungan antara bukit sekitarnya. Lokasinya berada di ketinggian 1.250 MDPL dan keberadaannya berada di atas pemukiman masyarakat Kampung Hakim Bale Bujang. Bukit Bur Telege merupakan lingkup hutan lindung, karena masih asri dan memiliki beberapa flora dan fauna yang dilindungi. Jalan menuju ke lokasi ini sudah dibuka sejak lama dengan tembusan ke wilayah une-une. Tetapi baru beberapa tahun belakang, program perbaikan jalan beraspal baru saja dilaksanakan setelah kehadiran wisata di lokasi tersebut, sehingga saat ini jalan menuju ke lokasi ini sudah membaik.

Bur Telege merupakan kata dari bahasa Gayo, secara pengertiannya kata "Bur" berarti bukit atau gunung, sedangkan "Telege" berarti telaga. Secara ucapan, kata Bur Telege dapat dipahami sebagai "bukit atau gunung telaga". Sesuai dengan nama bukit ini, terdapat suatu cerita yang dipahami oleh masyarakat setempat dengan gambaran wilayah tersebut. Di lokasi bukit ini terdapat suatu telaga yang kerap dipercayai telaga ini tidak pernah kering airnya. Menurut cerita orang tua mereka dulu${ }^{1}$, telaga ini selalu mengaliri air walaupun saat musim kemarau. Sehingga pada masa lalu, masyarakat di sini memanfaatkan air tersebut sebagai bekal untuk dikonsumsi saat mencari kayu ke hutan.

Jarak menuju ke bukit Bur Telege ini dari pusat Kota Takengon berkisar 20 menit perjalanan atau setara $3 \mathrm{Km}$. Saat sudah sampai di Kota Takengon terlihat dari kejauhan bukit sebelah kanan yang bertuliskan Highlind Gayo dan Tanoh Gayo yang berwarna putih bening dan merah. Lokasi bukit Bur Telege itu berada di tulisan tersebut. Namun walaupun lokasinya terlihat dengan jelas dari kejauhan, untuk menuju ke tempat tersebut seorang pengunjung harus melewati perkotaan terlebih dahulu dan mengarahkan perjalanannya ke pasar induk Kota Takengon.

\footnotetext{
${ }^{1}$ Istilah orang tua di sini sebenarnya dipahami sebagai nenek moyang, atau orang yang dulu pernah hadir dan beraktivitas di tempat ini. Masyarakat menyebutnya dengan sebutan "Orang tua kami dulu"
} 
Ada tiga faktor utama yang mendorong mereka melakukan perubahan tempat ini sebagai pengembangan wisata berkelanjutan. Pertama, keinginan merubah stereotip kampung, kedua mengembalikan keaktifan pemuda dalam partisipasi di kampungnya serta yang ketiga pengorganisasian pengambilan iuran parkir.

\section{Perubahan Stereotip Kampung}

Kampung Hakim Bale Bujang mendapatkan stereotip sebagai kampung preman, tempat maksiat, tempatnya berkumpul pemuda untuk ngelem. Stereotip tersebut menjadi cerita umum bagi masyarakat Takengen. Beberapa informan bercerita hal tersebut dengan bangga saat ini, seperti Pak Assaruddin, Pak Reje dan beberapa pemuda kampung. Pasalnya, lokasi yang membuat mereka dahulu tidak percaya diri saat ini menjadi salah satu penghasil pundi bagi masyarakat sekitar. Selain praktek kenakalan remaja yang sering terjadi di kawasan Bur Telege tersebut, praktek kekerasan juga sering terjadi di jalur yang menghubungkan kawasan tersebut dengan Lut Tawar. Apalagi bagi muda-mudi yang melewati tempat tersebut, jika tak sopan maka tinju akan melayang.

Begitulah kira-kira gambaran Bur Telege masa lalu, saat ini cerita tersebut menjadi kebanggaan bagi mereka. Karena mereka telah berbenah, berubah ke arah yang lebih baik sesuai dengan kesepakatan bersama. Perubahan yang dijalankan pun secara perlahan-lahan melaui pendekatan kepada pemuda kampung dan memperbanyak musyawarah antar masyarakat. Apalagi saat Bur Telege Lalu hadir dengan konsep destinasi wisata Bur Telege. Image kampung berubah secara drastis dari image buruk sebagai kampung preman menjadi image baik sebagai kampung wisata. Keberhasilan ini berkat kerjasama masyarakat kampung secara bersama. Masyarakat mampu merubah sikap dan pemahamannya dengan baik terhadap pendatang yang berkunjung atau melintasi ke tempat mereka. Dengan demikian, secara menyeluruh mereka sudah dapat berkompromi dan sudah dapat bekerjasama dalam membangun kampungnya. 


\section{Mengembalikan Keaktifan Pemuda Kampung}

Beberapa tahun sebelum pengembangan wisata Bur Telege dimulai, Bapak Assaruddin melihat pemuda kampung yang berada di luar kampung sangat betah di warnet. Pada masa itu, internet sedang naik daun sebagai fasilitas teknologi yang banyak memikat masyarakat. Sebelum Bapak Assaruddin aktif sebagai perangkat kampung, beliau berprofesi sebagai supir bus mini (L300) lintas Takengon-Banda Aceh. Setiap kali berpergian dan pulang ke Takengon, beliau melihat beberapa pemuda kampung yang banyak menghabiskan waktunya di warnet yang berdekatan dengan loket bus mini. Kala itu loket tersebut berada berdekatan dengan pasar induk Kota Takengon atau tidak jauh dari kampung mereka. Para pemuda menghabiskan waktunya di warnet untuk bermain game online atau menonton youtube. Hal tersebut sudah lama dilihat oleh Bapak Assaruddin kala itu dan beliau merasa kenapa pemuda tidak betah dikampungnya kemungkinan disebabkan oleh hal tersebut. bahkan Pak Reje bernama Musriadi pun bertanya terkait dengan pemandangan tersebut di kampung, "mengapa para pemuda tidak betah di kampung".

Setelah dimusyawarahkan dengan beberapa elemen kampung dan orang tua, akhirnya mereka memutuskan untuk membangun "warung kampung". Selain persoalan pemuda seperti diatas, persoalan menciptakan lapangan kerja dan pemasukan serta pemusatan kegiatan aktivitas pemuda turut melatarbelakari pembangunan 'warung kampung' tersebut. Pada kala itu, para masyarakat membeli sebuah rumah kosong yang berlokasi di seputaran kantor reje sekarang ini. Rumah tersebut dimiliki oleh masyarakat sekitar dan tidak ditinggali lagi. Rumah ini dibeli dengan swadaya masyarakat. Artinya masyarakat menyumbang iuran uang bersama untuk membeli rumah tersebut, dalam istilah lainnya mereka berinfak untuk kampung. Sehingga rumah ini mutlak sebagai aset Kampung Hakim Bale Bujang sampai dengan sekarang.

Dengan kehadiran warung kampung ini, para orang tua dan juga struktur kampung dapat dengan mudah mengontrol para pemuda di kampung. Berada pada satu titik kumpul, para pemuda mulai terlihat aktif berada di kampungnya. Juga keberadaan fasilitas wifi, mereka dapat menggunakan Hp untuk mengakses internet. Selain itu, fasilitas TV juga sangat bermanfaat bagi masyarakat sebagai 
ajang tontonan, seperti saat edisi pertandingan bola. Mereka dapat menontonnya di warung ini dengan masyarakat kampungnya.

\section{Parkir di Hari Minggu}

Bermula semangat yang pudar setelah insiden kebakaran yang terjadi di sekitaran bukit dan menghanguskan pohon alpukat yang ditanami oleh masyarakat, terjadi kejenuhan yang dialami oleh masyarakat pada saat itu. Namun terdapat beberapa orang yang belum putus semangatnya, mengajak beberapa masyarakat terkhususnya pemuda untuk melakukan perawatan pada pohon alpukat yang tidak dilahap oleh api. Keberadaan pohon alpukat yang masih hidup berada di bukit Bur Telege, salah satu lokasinya berdekatan dengan tulisan Higland Gayo yang dibangun oleh Dinas Pariwisata setempat.

Saat itu, beberapa masyarakat terkhususnya para pemuda melakukan perawatan kembali terhadap pohon alpukat tersebut dengan dipimpin oleh orang tua setempat. Mereka optimis merawatnya dan memberi pemupukan pada pohon alpukat yang dijelajahnya. Serta saat itu, masyarakat yang ikut merawat juga membersihkan lokasi di sekitaran pohon alpukat.

Namun pada suatu hari, saat para masyarakat duduk di warung kampung sembari bercerita bersama, mereka membahas terkait pohon alpukat di atas bukit Bur Telege. Saat cerita itu berlangsung bersama, pembahasan mereka menjerumus pada kunjungan orang-orang ke wilayah bukit Bur Telege ini. Mereka menyadari bahwa bukit Bur Telege ini memiliki pemandangan yang indah di puncaknya, maka banyak orang yang berkunjung ke bukit Bur Telege untuk menenangkan pikiran dan menikmati pemandangan.

Saat cerita ringan berlangsung, timbul suatu ide oleh masyarakat untuk mengambil jasa parkir di lokasi bukit Bur Telege. Pengambilan parkir ini adalah sebagai uang jajan para pemuda setempat sehari-hari agar tidak menganggur di kampung. Pada waktu itu, lokasi bukit Bur Telege bulum bersih dan hanya terdapat jalan setapak yang menuju ke tulisan Higland Gayo. Di sekitaran tulisan tersebut juga terdapat halte yang dibangun oleh Dinas Pariwisata yang pembangunannya bersamaan dengan tulisan tersebut. 
Saat itu, pengambilan iuran parkir berjalan dengan aman dan baik karena para pengunjung merasa aman saat meletakkan motor di titik bawah. Karena pada dasarnya, kendaraan pengunjung pada saat itu belum bisa diarahkan ke atas puncak. Namun kala itu, Bapak Musriadi selaku reje kampung tidak setuju dengan pengutipan biaya parkir yang dilakukan oleh pemuda setempat. Menurut penjelasan Bapak Musriadi bahwa pengutipan parkir tersebut tidak sesuai dengan fasilitas yang ada di bukit Bur Telege. Ini dapat dipahami sebagai pemalakan pada para pengunjung karena mereka tidak sepenuhnya mendapatkan fasilitas yang memadai. Beliau juga menjelaskan bahwa di wilayah danau Lut Tawar pernah terjadi tren pengutipan parkir setiap hari minggu. Beliau mengambil sikap pada para pemuda agar tidak mengambil iuran parkir kepada para pengunjung yang datang ke bukit Bur Telege ini.

Setelah kejadian itu, Bapak Musriadi kedatangan 2 (dua) pemuda ke kantor reje. Mereka menanyakan apa maksud reje melarang pengutipan parkir di bukit Bur Telege. Bapak Musriadi menjelaskan maksud dan tujuannya melarang para pemuda mengambil iuran parkir di tempat tersebut. Beliau menjelaskan kembali bahwa di tempat itu tidak ada hal yang dapat ditawarkan kepada pengunjung untuk dinikmati saat berada di lokasi tersebut. Namun pada akhirnya, dua pemuda ini menanyakan, apakah boleh tempat itu dibersihkan dan setelah dibersihkan, kami kembali mengutipkan iuran parkir? Bapak Musriadi kala itu sangat setuju dengan saran yang disampaikan oleh pemuda tersebut, dan beliau juga mendukung kegiatan yang dilakukan oleh pemuda. Barulah setelah itu, pemuda mulai membersihkan bukit Bur Telege dan berkreasi untuk menambah spot foto.

\section{Pemanfaatan Dana Desa Untuk Pengembangan Wisata : Pencapaian dan Target yang Lebih Besar}

Setelah kesuksesan didapatkan oleh masyarakat Hakim Bale Bujang yang telah menata dan mengorganisasikan kegiatan para pemuda yang terpusat dan terfokus pada pengembangan sektor ekonomi dari pemanfaatan keberadaan Bur Telege dan warung kampung. Masyarakat Kampung Hakim Bale Bujang semakin percaya diri karena berbagai hambatan telah mereka lewati. Berbekal kepercayaan tersebut dan modal sosial yang semakin bertambah, pada tahun 2017 mereka 
mulai membangun kawasan Bur Telege dengan menambah beberapa fasilitas tambahan dengan menggunakan dana desa. Pada saati itu mereke membeli Genset dengan plot anggaran sebesar Rp. 10.000.000. Setelah itu, alokasi dana desa sudah rutin diplotkan untuk pengembangan sarana dan prasana Kawasan Wisata Bur Telege.

Secara umum, alokasi anggaran dana desa untuk pembangunan Bur Telege sebagai destinasi wisata dapat dilihat pada tabel di bawah ini:

Tabel. Jumlah Penggunaan dana desa untuk pengembangan wisata Burtelege

\begin{tabular}{|c|c|c|c|c|c|}
\hline No. & Tahap & Tahun & Jumlah Dana & Pengerjaan & Ket \\
\hline \multirow[t]{8}{*}{1.} & \multirow[t]{8}{*}{ Pertama } & \multirow[t]{8}{*}{2017} & \multirow[t]{8}{*}{10 Juta } & Pengadaan Ginset Besar & Selesai \\
\hline & & & & Pengadaan Terpal & Selesai \\
\hline & & & & Pengadaan Tenda Murah & Selesai \\
\hline & & & & Pengadaan Mesin Babat & Selesai \\
\hline & & & & Pengadaan mesin Sinso & Selesai \\
\hline & & & & $\begin{array}{ll}\text { Pengadaan } & \text { Alat } \\
\text { Pertukangan } & \end{array}$ & Selesai \\
\hline & & & & $\begin{array}{l}\text { Pembangunan } \\
\text { Darurat }\end{array}$ & \\
\hline & & & & $\begin{array}{l}\text { Kebutuhan } \\
\text { pengerjaan }\end{array}$ & Selesai \\
\hline 2. & Kedua & 2017 & 9 Juta & Pembuatan MCK & Selesai \\
\hline 3. & Ketiga & 2018 & 2 Juta & $\begin{array}{lr}\text { Memfasilitasi } & \text { biaya } \\
\text { pengerjaan } & \text { perbaikan } \\
\text { jalan } & \\
\end{array}$ & Selesai \\
\hline \multirow[t]{7}{*}{4.} & \multirow[t]{7}{*}{ Keempat } & \multirow[t]{7}{*}{2018} & \multirow[t]{7}{*}{244 Juta } & Pembangunan Aula & Selesai \\
\hline & & & & Pembangunan Spot Foto & Selesai \\
\hline & & & & $\begin{array}{l}\text { Pembangunan Playing } \\
\text { Fox }\end{array}$ & Selesai \\
\hline & & & & $\begin{array}{l}\text { Pembangunan Pos Tiket } \\
\text { Sederhana }\end{array}$ & Selesai \\
\hline & & & & Cat Jalan setapak & Selesai \\
\hline & & & & Perbaikan MCK & Selesai \\
\hline & & & & $\begin{array}{ll}\text { Kebutuhan } & \text { Selama } \\
\text { Pengerjaan } & \end{array}$ & Selesai \\
\hline \multicolumn{3}{|c|}{ Jumlah keseluruhan } & \multicolumn{3}{|l|}{265 Juta } \\
\hline
\end{tabular}

Sumber: Wawancara bersama Bapak Assaruddin

Dari semua tahapan pemberian dana desa ini, total keseluruhan dana desa untuk pengembangan wisata Bur Telege ini mencapai Rp. 265.000.000 juta rupiah. Dengan beberapa tahap alokasi dana serta beberapa tahap pembangunan di lokasi wisata, akhirnya wisata Bur Telege kala itu sudah membaik dari sebelumnya. Beberapa fasilitas yang hadir kala itu setelah pembangunan menjadi fasilitas yang dapat dimanfaatkan oleh para wisatawan. Jumlah tersebut merupakan jumlah 
keseluruhan atas pemanfaatan dana desa untuk pengembangan wisata Bur Telege ini.

Selain peran serta masyarakat secara swadaya dalam pengerjaan beberapa fasilitas tambahan untuk pembangunan destinasi wisata Bur Telege, peran serta pemerintah dan bantuan lainnnya turut serta berkontribusi terhadap pengembangan kawasan wisata Burtelege. Beberapa fasilitas yang dibangun setelah itu dapat dilihat pada tabel berikut ini :

Tabel. Penambahan fasilitas yang diberikan oleh pihak luar

\begin{tabular}{|c|c|c|c|c|c|c|}
\hline No. & Penyumbang & Tahun & $\begin{array}{c}\text { Jumlah } \\
\text { Dana }\end{array}$ & Fasilitas & Manfaat & Ket. \\
\hline 1. & $\begin{array}{l}\text { Dirjen } \\
\text { Kemendes }\end{array}$ & 2018 & $\begin{array}{l}600 \\
\text { Juta }\end{array}$ & $\begin{array}{l}\text { - } \text { MCK } \\
\text { - Jalan } \\
\text { Setapak } \\
\text { - } \text { Soralsel } \\
\end{array}$ & $\begin{array}{l}\text { Masyarakat } \\
\text { dan Wisatawan }\end{array}$ & Selesai \\
\hline \multirow[t]{2}{*}{2.} & & 2018 & $\begin{array}{l}600 \\
\text { Juta }\end{array}$ & $\begin{array}{l}\text { - Grafiti } \\
\text { - Gapura } \\
\text { - Rabat Beton }\end{array}$ & $\begin{array}{l}\text { Masyarakat } \\
\text { dan Wisatawan }\end{array}$ & Selesai \\
\hline & Dinas Pariwisata & - & $\begin{array}{l}1 \\
\text { Milyar }\end{array}$ & $\begin{array}{l}\text { - Kantor } \\
\text { Masyarakat } \\
\text { - Warung } \\
\text { - Jalan Setapak } \\
\text { - Panggung } \\
\text { Seni }\end{array}$ & $\begin{array}{l}\text { Masyarakat } \\
\text { dan Wisatawan }\end{array}$ & Selesai \\
\hline 3. & Dinas PU & $\begin{array}{l}2019- \\
2020\end{array}$ & $\begin{array}{l}10 \\
\text { Milyar }\end{array}$ & $\begin{array}{l}\text { - Perbaikan } \\
\text { Jalan } \\
\text { Beraspal }\end{array}$ & $\begin{array}{l}\text { Masyarakat } \\
\text { dan Wisatawan }\end{array}$ & Selesai \\
\hline 4. & Bank Indosesia & 2020 & $\begin{array}{l}500 \\
\text { Juta }\end{array}$ & $\begin{array}{l}\text { - Tugu } \\
\text { - TPS } \\
\text { - Oven Kue } \\
\text { - Peralatan } \\
\text { Menjahit } \\
\end{array}$ & $\begin{array}{l}\text { Masyarakat } \\
\text { dan Wisatawan }\end{array}$ & Selesai \\
\hline 5. & $\begin{array}{l}\text { Alaidin Abu } \\
\text { Abbas }\end{array}$ & - & $\begin{array}{l}500 \\
\text { Juta }\end{array}$ & $\begin{array}{l}\text { - Mesin Air } \\
\text { - Tangki Air } \\
\text { - Pipa } \\
\text { Penyaluran } \\
\text { Air }\end{array}$ & $\begin{array}{l}\text { Masyarakat } \\
\text { dan Wisatawan }\end{array}$ & Selesai \\
\hline 6. & NN & 2019 & - & $\begin{array}{l}\text { - Villa } \\
\text { (Penginapan) }\end{array}$ & Wisatawan & Selesai \\
\hline
\end{tabular}

Sumber: Wawancara dengan Bapak Assaruddin (Ama Gito)

Pengembangan kawasan wisata terus dilakukan oleh pihak kampung Hakim Bale Bujang, selain menggunakan dana desa, kerjasama dan keinginan dari pihak lainnya juga terus disambut untuk pengembangan kawasan wisata yang berbanding lurus dengan pengembangan sektor ekonomi masyarakat. Bahkan pengembangan pemanfaatan lahan terus dijajaki oleh aparatur Kampung Hakim 
Bale Bujang, untuk menyiasati agar keberadaan Kawasan Bur Telege yang sudah masuk dalam hutang lindung, kerjasama dengan pihak LHK dilakukan dan aparatur Kampung telah menandatangani naskah perjanjian kerjasama pengelolaan hutan dalam bentuk kegiatan jasa lingkungan dan ekowisata yang berlokasi di bukit Bur Telege, Kampung Bale Bujang. Perjanjian ini disepakati atas peran andil masyarakat dalam pengelolaan hutan lindung sebagai distinasi wisata.

Terbukti, wisatawan mulai nyaman berkunjung ke Bur Telege, akses menuju kesana semakin mudah dan terkoneksi dengan fasilitas lainnya seperti penginapan dan kantin. Tercatat Bur Telege pernah dikunjungi oleh 1000-1500 an pengunjung pada hari raya tahun 2018 dengan estimasi pemasukan sampai Rp. 122.000.000 selama dua hari saat hari raya idul fitri.

\section{Kesimpulan}

Dari data etnografis yang telah dijelaskan di atas, terlihat bahwa ada peran serta masyarakat dalam proses pembangunan desa melalui pengembangan destinasi wisata Bur Telege yang kemunculannya menjadi salah satu rasa syukur di tengah masyarakat. Rasa syukur itu terhadap pengembangan ekonomi masyarakat melalui pembukaan lokasi wisata, perubahan stereotip kampung, serta tertutupnya akses lokasi terhadap praktik dan aktivitas yang menjurus pada maksiat.

Swadaya masyarakat serta dukungan dari aparatur Kampung Hakim Bale Bujang melalui alokasi dana desa menjadi pelecut bagi masyarakat untuk membangun destinasi wisata Bur Telege menjadi lebih baik dan nyaman bagi wisatawan. Hal tersebut berdampak pada ketertarikan pihak luar baik unsur pemerintah maupun swasta untuk berkontribusi terhadap pemajuan ekonomi masyarakat yang berbanding lurus dengan upaya pemanfaatan fungsi hutan di lokasi Bur Telege yang berarsiran dengan kawasan hutan lindung.

Dengan hasil penelitian seperti yang sudah ditunjukkan di atas, penulis dapat menyimpulkan bahwa :

Pertama, desa membangun dilihat dari sisi makna pembangunan desa berarti bahwa desa mempunyai kemandirian dalam membangun dirinya (self 
development). Kedua, desa membangun dilihat dari sisi pendekatan pembangunan berarti desa bukan menjadi objek dan lokasi proyek pembangunan, melainkan desa menjadi basis, subjek dan arena pembangunan. Ketiga, desa membangun dilihat dari sisi aktor pembangunan berarti bahwa ide tentang pembangunan yang digerakkan oleh desa (village driven development), sebagai alternatif atas pembangunan yang digerakkan oleh masyarakat (community driven development) dalam penanggulangan kemiskinan melalui pemberdayaan, yang sudah dijalankan oleh pemerintah selama hampir dua dekade terakhir dalam bentuk PNPM Mandiri Perdesaan. Keempat, "desa membangun Indonesia" adalah emansipasi desa untuk Indonesia, yakni desa menjadi basis kehidupan dan penghidupan (basis sosial, basis ekonomi, basis politik, basis budaya), termasuk desa bermanfaat mengelola kepentingan masyarakat maupun melayani kebutuhan warga desa. 


\section{Daftar Pustaka}

Abidin, Zaenal. (2012). "Manifestasi dan Latensi Lembaga Filantropi Islam dalam Praktik Pemberdayaan Masyarakat: Suatu studi di Rumah Zakat Kota Malang". Salam: Jurnal Studi Islam, 15(2): 197-214

Bungin, Burhan. (2010). Analisa Data Penelitian Kualitatif. Jakarta: Rajawali Press

Badan Pusat Statistik. 2020. Kecamatan Lut Tawar Dalam Angka. Takengon. Nomor Katalog: 1102001.1106031

Creswell, John W. (2010). Research Design Pendekatan Kualitatif, Kuantitatf dan Mixed. Jakarta: Pustaka Pelajar

Eko, Sutoro dkk. (2014). Desa Membangun Indonesia. Yogyakarta: FPPD

Faisal, Sanapiah. (1989). Fotmat-Format Penelitian Sosial. Jakarta: Rajawali

Hermawan, Hary. (2016). "Dampak Pengembangan Desa Wisata Nglanggeran terhadap Ekonomi Masyarakat Lokal”. Jurnal Pariwisata, 3(2): 105-117.

Karimah, Faizatul dkk. (2014). "Pengelolaan Alokasi Dana Desa dalam Pemberdayaan Masyarakat: Studi pada Desa Deket Kulon Kecamatan Deket Kabupaten Lamongan". Jurnal Administrasi Publik (JAP), 2(4): 597-602.

Kementrian Keuangan. (2017). Buku Pintar Dana Desa. Jakarta

Koentjaraningrat. (1991). Metode- Metode Penelitian Masyarakat. Jakarta: Gramedia Pustaka Utama,

Shri Ahimsa Putra, Heddy. (2014). Pariwisata dan Perubahan Kebudayaan. Proposal tidak diterbitkan. Yogyakarta: Universitas Gadjah Mada.

Saragih, Ramainim dan Sarwititi Agung. (2017) "Peran Komunikasi Politik Pemerintah dalam Upaya Peningkatan Partisipatif Masyarakat dalam Pemanfaatan Dana Desa: Penggalian Bentuk Komunikasi Warga Masyarakat Terhadap Penggunaan Dana Desa". Jurnal Reformasi, 7(1): 59-69.

Walpole, M.J. dan H.J. Goodwin. (2000). “Local Economic Impacts Dragon Tourism In Indonesia". Annals of Tourism Research. 77(3): 559-576 
Wilson, Terry. (1996). The Empowerment Mannual. London: Grower Publishing Company.

\section{UU \& Peraturan Pemerintah}

Undang-undang Nomor 6 Tahun 2014 Tentang Desa

Peraturan Menteri Dalam Negeri Republik Indonesia Nomor 113 Tahun 2014 tentang Pengelolaan Keuangan Desa.

Peraturan Menteri Desa, Pembangunan Daerah Tertinggal, dan Transmigrasi Republik Indonesia Nomor 22 Tahun 2016 tentang Penetapan Prioritas Penggunaan Dana Desa Tahun 2017.

\section{Media Online}

Serambinews.com. Bur Telege, Objek Wisata Baru di Takengon, Diakses pada 10 September 2018 dari situs: http://aceh.tribunnews.com/2017/06/30/burtelege-objek-wisata-baru-di-takengon

Serambinews.com. Sarang Maksiat itu Kini jadi lokasi wisata. Diakses pada 10 september 2018 dari situs: http://aceh.tribunnews.com/2018/09/22/sarang-maksiat-itu-kini-jadilokasi-wisata-senyum-bebujang-bale-di-bur-telege

Kompas.com. 2019. Tempat Wisata Baru di Aceh untuk Mengamati Burung, Bur Mulo Forest Park. Terbit 01/11/2019, Akses 21/10/2021. https://travel.kompas.com/read/2019/11/01/151500427/tempat-wisatabaru-di-aceh-untuk-mengamati-burung-bur-mulo-forest-park?page=all

Lintas Gayo. Adi Bale Kembali Terpilih Sebagai Reje Kampung Hakim Bale Bujang. terbit pada 25/2/2021. akses 12/10/2021. https://lintasgayo.com/80187/adi-bale-kembali-terpilih-menjadi-rejekampung-hakim-bale-bujang.html

Lintas Gayo. Adi Bale Kembali Terpilih Sebagai Reje Kampung Hakim Bale Bujang. terbit pada 25/2/2021. akses 12/10/2021. https://lintasgayo.com/80187/adi-bale-kembali-terpilih-menjadi-rejekampung-hakim-bale-bujang.html 
DLHK Aceh. Penggiat Lingkungan Suhaimi Hamid dan Reje Kampung Hakim Bale Bujang Misriadi Terima Penghargaan Dari KLHK. Terbit 6/12/2019, akses 13/10/2021.

https://dlhk.acehprov.go.id/2019/12/penggiat-lingkungan-suhaimihamid-dan-reje-kampung-hakim-bale-bujang-misriadi-terimapenghargaan-dari-klhk/

HakimBaleBujang. 2020. Bank Indonesia kunjungi Bur Telege, Usung Program Desa Wisata. terbit 4/3/2020, akses 15/10/2021.

http://hakimbalebujang.desa.id/2020/03/04/bi-kunjungi-bur-telegeusung-program-desa-wisata/

Eda, Fikar W. SerambiNews.com. 2019. Reje Hakim Bale Bujang Aceh Tengah Terima Penghargaan dari Kemen LHK. Terbit pada 2/12/2019, akses pada 18/10/2021. https://aceh.tribunnews.com/2019/12/02/reje-hakim-balebujang-aceh-tengah-terima-penghargaan-dari-kemen-lhk

HakimBaleBujang. 2019. Anggota DPR RI TA Khalid Puji Kampung Hakim Bale Bujang Takengon, Terbitkan Qanun Lingkungan Hidup. Terbit 29/11/2019, akses 18/10/2021. http://hakimbalebujang.desa.id/2019/11/29/anggotadpr-ri-ta-khalid-puji-kampung-hakim-bale-bujang-takengon-terbitkanqanun-lingkungan-hidup/

SuaraGayo. 2021. Bupati Aceh Tengah Bangga Hakim Bale Bujang dan Bebesen Masuk 300 Besar Anugerah Desa Wisata. Terbit pada 19/8/2021, akses 18/10/2021. https://suaragayo.com/bupati-aceh-tengah-bangga-hakimbale-bujang-dan-bebesen-masuk-300-besar-anugerah-desa-wisata/

HakimBaleBujang. 2020. Kampung Hakim Bale Bujang dan Pendamping Desa Selenggarakan Pelatihan Pengelolaan BUMK. Terbit pada 14/7/2020, akses 18/10/2021. http://hakimbalebujang.desa.id/2020/07/14/hakim-balebujang-dan-pendamping-desa-adakan-pelatihan-pengolaan-bumk/

Kompas.com. 2019. Tempat Wisata Baru di Aceh untuk Mengamati Burung, Bur Mulo Forest Park. Terbit 01/11/2019, Akses 21/10/2021. https://travel.kompas.com/read/2019/11/01/151500427/tempat-wisatabaru-di-aceh-untuk-mengamati-burung-bur-mulo-forest-park?page=all

DLHK ACEH. 2019. Penandatanganan Perjanjian Kerjasama UPTD KPH Wilayah II DLHK Aceh Dengan Kampung Hakim Bale Bujang Tentangf Pengelolaan Hutan. Terbit pada 5/9/2019, akses pada 22/10/2021. https://dlhk.acehprov.go.id/2019/09/penandatanganan-perjanjiankerjasama-uptd-kph-wilayah-ii-dlhk-aceh-dengan-kampung-hakim-balebujang-tentang-pengelolaan-hutan/ 